\title{
The Effects of Monday Thursday Fasting on Blood Pressure and Oral Hygiene Level on Clinical Dental Profession Student
}

\author{
Erlina Sih Mahanani ${ }^{1, *}$ Dinda Triani Ahyati ${ }^{2}$ Hana Aulia Hapsari ${ }^{3}$
}

\author{
${ }^{I}$ Department of Dental Biomedic, School of Dentistry, Faculty of Medicine and Health Science, Universitas Muhammadiyah Yogyakarta \\ ${ }^{2}$ School of Dentistry, Faculty of Medicine and Health Science, Universitas Muhammadiyah Yogyakarta \\ ${ }^{3}$ School of Dentistry, Faculty of Medicine and Health Science, Universitas Muhammadiyah Yogyakarta \\ ${ }^{*}$ Corresponding author. Email: erlina.sih@umy.ac.id
}

\begin{abstract}
Fasting has many health benefits for the human body as there is a detoxification process or release of toxic substances in the bod. One of the benefits are on blood pressure and oral hygiene. This research aims to identify the difference of blood pressure and oral hygiene level between clinical dental profession students who have a habitual and those who have no habitual doing Monday Thursday fasting. The Mann-Whitney U-Test result for blood pressure category showed a $p$ value $0,006(p<0,05)$. There was a difference in the blood pressure among two groups. The oral hygiene level category showed that $p$ value 1,000 ( $p>0,05)$ and , there was no significant difference in the oral hygiene level. Based on this study's result, it can be concluded that the clinical dental profession students with a habit of doing Monday Thursday fasting had normal blood pressure compared to those with no habitual. However at the oral hygiene level, all students had good oral hygiene due to sufficient oral health knowledge.
\end{abstract}

Keywords: blood pressure, Monday Thursday Fasting, oral hygiene level

\section{INTRODUCTION}

Fasting is good to avoid something exaggerating and excessive. Someone who let their stomach full in habitual could harm their heart as a blood pump. Fasting is an alternative way to avoid the excessive eating habit of a human [1]. There are so many health benefits of fasting due to detoxification of toxic substances removal from our bodies. The decrease of cortisol hormone produced by the adrenal glands during fasting could lower stress levels. Fasting can also change lifestyle and bad eating habits such as smoking and craving for sweets. In terms of the benefits, Monday Thursday fasting has become the essential sunnah fasting among others considering its significant benefit $[2,3]$.

Fasting is important to keep blood pressure normal. Excessive eating habits especially fatty food could increase cholesterol and fat rate on blood which will impact blood pressure. This is due to the layer formed from fat and cholesterol on blood vessels blocking the rate of blood flow [4].

Fasting people do not eat and drink for nearly twelve hours, thus the intake amount will not be as much as usual. It will affect the number of bacteria in their mouth since more food comes into their mouth, indicating more varieties will be found in their mouth. Otherwise, the human lifestyle tends to be more in order and more likely to do other sunnah worship by fasting. Human tends to have better selfcontrol when they do fasting since fasting will protect human from their lust and something inappropriate [5].
When human beings can control their lust, there will be peace upon them. It will decrease their emotional stress level. According Afifi's research about the effect of Ramadhan Fasting on a daily lifestyle, there is also a decrease in emotional stress levels during fasting [6]. The decrease in emotional stress will bring peace to an individual. Peacefulness will stimulate the parasympathetic nerve. Sympathetic nerve stimulations will make cardiac muscle contraction works faster while parasympathetic nerve stimulation will get slower. Otherwise, the lower rate of emotional stress will affect the secretion system and saliva $\mathrm{pH}$ in the mouth, which will be very useful for the self-cleansing process inside the mouth [7].

Blood pressure has been an indicator to measure the cardiovascular system. It is pressure by blood against blood vessels affected by blood volume and blood vessel elasticity. Higher blood pressure is caused by increased blood volume or blood vessel elasticity and vice versa, the lower blood volume will decrease blood pressure [8].[9]. According to World Health Organization (WHO), normal blood pressure for adults is around $120 / 80 \mathrm{mmHg}$ up to $130 / 85 \mathrm{mmHg}$. When there is an increase in blood pressure above normal, it is called hypertension. There are some factors that could increase the risk or tendency of people with hypertension according to individual characteristics, such as age, sex, tribe, genetic factor, external factors, obesity, stress, smoking, alcohol, salt consumption, and any others [10].

The health of the body and soul has been the most important thing in human life, not only in general but specifically on oral hygiene and health since it can affect the whole body's speech 
function, digestion, and self-esteem. Fasting Muslims have two mealtimes, namely iftar time on maghrib and sahur before dawn. The length of fasting time is different according to the world time zone, around $11-18$ hours every day on average [11]. During the fasting hour, humans are not allowed to eat or drink anything. It can affect mouth condition for changing of $\mathrm{pH}$ and saliva secretion as a self-cleansing agent on the mouth. The decrease of liquid intake during fasting could also lower the volume of liquid inside the body, affecting the blood circulation process. The decreased volume of the liquid inside the body will affect blood circulation in the blood vessel and could lower blood pressure [12].

There is no scientific research about the effect of MondayThursday fasting on blood pressure and oral hygiene. Therefore, this research has been conducted to identify the differences between blood pressure and oral hygiene of Clinical Dental profession student UMY with Monday Thursday fasting habit.

\section{MATERIAL AND METHOD}

Samples in this research were Clinical Dental profession student UMY, second semester in Rumah Sakit Gigi dan Mulut UMY with inclusion criteria, such as:
1. Healthy student at the moment they are MondayThursday fasting.

2. Students that are willing to participate in.

Meanwhile, the research exclusion criteria:

Students performing brushing teeth less than twice a day

1. Students with fixed orthodontic appliances

2. Students with a smoking habit

The sample used for this research, including drop out, ware 54 volunteers and they had filled in informed consent. The measurement of blood pressure and oral hygiene level has been conducted to volunteer. Blood pressure measurements were done three times using a digital thermometer (Omron, USA) with 15 of time interval. Oral hygiene level measurement had been done for one time using the Oral Hygiene Index Simplified (OHI-S). Data collection and measurement used in this study were SPSS.

\section{RESULT AND DISCUSSION}

The description of students as a volunteer in this study was presented in Table 1. Students' blood pressure measurement and oral hygiene level with Monday-Thursday fasting habit and those who do not have Monday-Thursday fasting are shown in Table 2 and 3.

Table 1. Description based on age

\begin{tabular}{cccccc}
\hline & & Frequency & Percentage & $\begin{array}{c}\text { Valid } \\
\text { Percentage }\end{array}$ & $\begin{array}{c}\text { Cumulative } \\
\text { Percent }\end{array}$ \\
\hline Valid & 22 & 2 & 4,1 & 4,1 & 4,1 \\
& 23 & 28 & 57,1 & 57,1 & 61,2 \\
& 24 & 13 & 26,5 & 26,5 & 87,8 \\
& 25 & 2 & 4,1 & 4,1 & 91,8 \\
& 26 & 2 & 4,1 & 4,1 & 95,9 \\
& 27 & 2 & 4,1 & 4,1 & 100,0 \\
\hline & Total & 49 & 100,0 & 100,0 & \\
\hline
\end{tabular}

Table 2. Blood pressure category

\begin{tabular}{ccccc}
\hline & & \multicolumn{2}{c}{ Blood Pressure } & Total \\
\cline { 3 - 5 } & & upnormal & normal & upnormal \\
\hline Monday-Thursday & no habit & 20 & 13 & 33 \\
fasting habit & Habit & 3 & 13 & 16 \\
\hline Total & & 23 & 26 & 49 \\
\hline
\end{tabular}

Table 3. Oral Hygiene Index category

\begin{tabular}{cccc}
\hline & & OHI & Total \\
\cline { 3 - 4 } & & good & good \\
\cline { 3 - 4 } & habit & 33 & 33 \\
Monday-Thursday & no habit & 16 & 16 \\
fasting habit & & 49 & 49 \\
\hline
\end{tabular}


Table 4. Statistic analysis

\begin{tabular}{crr}
\hline & Blood Pressure & OHI S \\
\hline Mann-Whitney U & 153,500 & 264,000 \\
Wilcoxon W & 714,500 & 400,000 \\
Z & $-2,725$ &, 000 \\
Asymp. Sig. (2-tailed) &, 006 & 1,000 \\
\hline
\end{tabular}

Most students with habitual Monday-Thursday fasting has a normal blood pressure rate. The habit of having MondayThursday fasting has protected them from their lust and any other despicable behavior (Table 4). Students with habitual Monday-Thursday fasting indicates that they have done it in a certain period. This habitual routine could affect human health, one of which is on blood pressure rate and to avoid hypertension. Intermittent fasting could raise Brain Derivat Nutrophic Factor (BDNF) that lower systolic and diastolic blood pressure by activity parasympathetic system. Brain Derivat Nutrophic Factor can cause acetylcholine release by the vagus nerve that lower heart contraction frequency [13].

For those who do not Monday-Thursday fasting, the result of their blood pressure measurement tends to be beyond normal. Toledo explained in their research about safety, health improvement, and well-being to 1422 subject that have been fasting for 4 to 21 days. The research showed more significant decrease in systolic and diastolic blood pressure in a more extended period of fasting group category, without any distinction on the sex category. Blood pressure showed a significant decrease but it was still higher than the lowest normal range. These decrease might have been triggered by several factors such as increased parasympathetic activity due to neurotrophic factor release from the brain (BDNF) the increase in $\mathrm{Na}$ kidney excretion and the increase of natriuretic pep receptor sensitivity [14].

The oral hygiene category showed different results. Around 49 samples consisting of 33 humans without habitual MondayThursday fasting and 16 humans with habitual Monday Thursday fasting all have good oral hygiene (Table 3). Based on this $100 \%$ good result, we can conclude that there were no differences in oral hygiene levels between students with habitual Monday-Thursday, fasting routine and those who do not (Table 4) due to some factors.

Considering that the samples in this research are professional students of Clinical Dental with good oral health knowledge. The higher education level of someone will increase their knowledge [15]. Descriptive analytic research by Komeilian and Moghaddas to 880 subjects who had fasting in Teheran concluded that gender and education (women and high education level) contributed to oral hygiene with consideration on orderly teeth brushing at minimum twice a day [16].

Furthermore, scaling is an oral treatment to remove plaque, calculus, and stain from all over the teeth surface and roots [17]. Other than that, some of the respondents are removable orthodontic appliances users that had regularly scaling treatment. Another research concluded by Sariri about alternative glucose saliva during Ramadhan fasting [18] explained that even though Ramadhan fasting affected saliva glucose, it would not affect glucose function in healthy human's saliva, since the concentration of glucose saliva depended on their intake during fasting. Normal saliva function was considered important for healthy oral mucose maintenance. It has been one among many factors that affect students' oral hygiene who routinely do Monday-Thursday fasting.

\section{CONCLUSION}

The clinical dental profession students with a habit of doing Monday-Thursday fasting have normal blood pressure compared to those with no habit. However, in the oral hygiene level, all students have good oral hygiene due to sufficient oral health knowledge.

\section{ACKNOWLEDGMENT}

Authors thank to Universitas Muhammadiyah Yogyakarta by LP3M Research Funding 2019 that supported this study.

\section{REFERENCES}

1. S. Ismail, R. Abdul Manaf R, A. Mahmud, Comparison of time-restricted feeding and Islamic fasting: a scoping review. East Mediterr Health J. 2019;25(4):239-245. https://doi.org/10.26719/emhj.19.011

2. C. Kirschbaum, E.G. Bono, N. Rohleder, C. Gressner, K.M. Pirke, A. Salvador, D.H. Hellhammer D.H., Effects of fasting and glucose load on free cortisol responses to stress and nicotine, J Clin Endocrinol Metab, 82(4) (1997), pp. 1101-5

3. S.P. Bauersfeld, C.S. Kessler, M. Wischnewsky, A. Jaensch, N. Steckhan, R. Stange, B. Kunz, B. Brückner, J. Sehouli, The effects of short-term fasting on qualityof life and tolerance to chemotherapy inpatients with breast and ovarian cancer: arandomized cross-over pilot study. BMC cancer (2018) 18: pp. 476-86.

4. L.K. Wulansari, B. Kaboosaya, M. Khan, M. Takahashi, H. Nakata, S. Kuroda, K. Aoki, S. Kasugai, Beneficial effects of fasting regimens on periodontal tissues in experimental periodontitis mice model. J Int Dent Med Res 2018; 11(2): pp. 362-369.

5. S. Ahmad, K. Goel, K.A. Maroof, P. Goel, M. Arif, M. Amir, and M. Abid, Psycho-Social Behaviour and Health Benefits of Islamic Fasting During the Month 
of Ramadan. J Community Med Health Educ (2012) 2:9, pp 1-4.

6. Z.E.M. Afifi, Daily practices, study performance and health during the Ramadan fast, Journal of the Royal Society of Health, (1997) 117 (4): pp. 231-235.

7. M. Cohena, R. Khalailab, Saliva $\mathrm{pH}$ as a biomarker of exam stress and a predictor of exam performance, Journal of Psychosomatic Research (2014) 77, (5), pp. 420-425.

8. P. Uangpairoj, and M. Shibata, Evaluation of vascular wall elasticity of human digital arteries using alternating current-signal photoplethysmography, Vasc Health Risk Manag. (2013) 9: pp. 283-295.

9. F. Samad, F. Qazi, M.B. Pervaiz, D.K. Kella, M. Mansoor, B.Z. Osmani, F. Mir, M.M. Kadir, Effects of Ramadan Fasting on Blood Pressure in Normotensive Males. J Ayub Med Coll Abbottabad (2015) 27 (2): pp. 338-42.

10. W. Kaplan, and B. Affandi, Blood Glucose Fluctuation During Ramadan Fasting in Adolescents With Type 1 Diabetes: Findings of Continuous Glucose Monitoring. Diabetes Care (2015) 38(10): pp.162-163.

11. M.H. Rouhani, and L. Azadbakht, Is Ramadan fasting related to health outcomes? A review on the related evidence, J Res Med Sci. (2014) 19(10): pp. 987-992.

12. Z.H. Rahim, H.B. Yaacob, Effects of fasting on saliva composition, J Nihon Univ Sch Dent (1991) 33(4): pp. 205-210.
13. B. Malinowski, K. Zalewska, A. Wesierska, Intermittent Fasting in Caridovascular Disorders-An Overview. Nutrients (2019); 11 : pp. 1-18.

14. F. Toledo, F. Grundler, A. Bergouignan, Safety, Health Improvement and Well-Being during a 4 to 21day Fasting Period in an Observational Study including 1422 Subjects. PLoS ONE (2019) 14 (1): pp. 1-23.

15. S. Ahamed, S. Moyin, S. Punathil, N.A. Patil, V.T. Kale, G. Pawar, Evaluation of the Oral Health Knowledge, Attitude and Behavior of the Preclinical and Clinical Dental Students. J Int Oral Health (2015) 7(6): pp. 65-70.

16. K. Komeilian, H. Moghaddas, Assessment of the Condition of Using Health Measures by Fastig People in Tehran City in 1382-83. Journal of Dental School, Shadid Beheshti University of Medical Science (2006) 24 (2): pp. 255-60.

17. C.R. Ramsay, J.E. Clarkson, A. Duncan,T.J. Lamont. P.A. Heasman, D. Boyers, et al. Improving the Quality of Dentistry (IQuaD): a cluster factorial randomised controlled trial comparing the effectiveness and costbenefit of oral hygiene advice and/or periodontal instrumentation with routine care for the prevention and management of periodontal disease in dentate adults attending dental primary care. Health Technol Assess (2018) 22(38).

18. R. Sariri, A. Varasteh, A., Erfani, Alternations in Salivary Glucose during Ramadan Fasting. HEALTH (2010) 2;2 (7): pp. 769-772. 